2020, Volume 14, International Conference Innovative Business Management \& Global Entrepreneurship (IBMAGE 2020), pages: 568-578 | https://doi.org/10.18662/lumproc/ibmage2020/41

\section{Entrepreneurial Perspectives on Some Bootlast Stems from the Collections of the Museum of the Lower Danube - Călăraşi}

\author{
Loredana-Andreea PĂUN \\ (PARNIC) $^{1 *}$, \\ Mihai-Claudiu NĂSTASE2 ${ }^{2}$, \\ Alexandru MITRU3
}

1 "Valahia" University-I.O.S.U.D./S.D.S.I., Targoviste, Romania, andreea.parnic@yahoo.com

* Corresponding author

2 "Valahia" University-I.O.S.U.D./S.D.S.I., Targoviste, Romania, nastase mc@yahoo.com

3 "Valahia" University-I.O.S.U.D./S.D.S.I., Targoviste, Romania, alexandrumitru@yahoo.com
Abstract: The Lower Danube Museum is an important resource for cultural tourism in the lower Danube area, especially through its archeological collections. Gumelnița culture is one of the most spectacular Chalcolithic cultures in the Balkans. During their existence on nowadays Romanian territory, these communities made a series of clay pieces that suggest a human foot, a rare form of its anthropomorphic plastic. In this study, we will discuss a type of artefact found in Gumelniţa settlements from Muntenia (Wallachia), preserved in the archaeology collection of the Lower Danube Museum from Călăraşi and its importance in the development of cultural tourism in the area. In the scientific literature, this type of piece is known as "boot last" stem or clay stem (clay foot). Compared to other categories of clay artefacts, this type of legs discussed in this paper is rather reduced in quantity, and they are found especially in Gumelniţa settlements form the south and the southeast of Muntenia. The pieces that make the subject of our study were discovered in the settlement Măgura Cuneşti, Călăraşi county, only one of them coming from the tell Sultana-Malu Roşu. As for the methodological approach, for a clearer analysis, we will consider the more or less known context of discovery, technical data, and last but not least regards on the technological form in connection with discussing possible interpretations of these objects.

Keywords: cultural tourism; foot-shoe; anthropomorphic plastic; Eneolithic; Gumelnița; Măgura Cunești.

How to cite: Păun (Parnic), L.-A., Năstase, M.-C., \& Mitru, A. (2020). Entrepreneurial Perspectives on Some Bootlast Stems from the Collections of the Museum of the Lower Danube - Călăraşi. In M. W. Staniewski, V. Vasile, \& A. Grigorescu (vol. eds.), Lumen Proceedings: Vol. 14. International Conference Innovative Business Management \& Global Entrepreneurship (IBMAGE 2020) (pp. 568-578). Iasi, Romania: LUMEN Publishing House. https://doi.org/10.18662/lumproc/ibmage2020/41 


\section{Introduction}

The Lower Danube Museum is an important resource for cultural tourism in the lower Danube area, especially through its archeological collections.

Gumelnița culture is one of the most spectacular Chalcolithic cultures in the Balkans. During their existence on nowadays Romanian territory, these communities made a series of clay artefacts that suggest a human foot, a rare form of its anthropomorphic plastic.

In the archaeology collection of the Lower Danube Museum, among other prehistoric relics, there are also artefacts of this type, attributed to the Gumelnița culture.

Even if some of them have already been published, we will resume them in this paper, analyzing them both in terms of the context of their discoveries, but also in terms of technology and possible interpretations of these objects.

In the subject's bibliography, this type of piece is known as a "boot last" or simply a clay foot.

Compared to other categories of clay pieces, the objects discussed here are reduced in quantity and are found especially in the Gumelnița settlements in the south and southeast of Muntenia.

All but one were discovered in the Măgura Cuneşti Gumelniţa settlement, Călăraşi County. The exception comes in the site of Sultana Malu Roşu, Mânăstirea commune, in the same county [Pl.1].

\section{Problem Statement}

Culture is a main "pull factor" which influences visitors initial decision to travel to destinations in different parts of the world. Cultural tourism embraces the desire and effort to travel to where a given peoples way of life in the past and present is most striking and the consumption of its cultural ideas. In Europe, cultural tourism consumption is dominated by the built environment - museums and monuments. Museums are undoubtedly the most popular form of cultural attraction for cultural tourists in Europe [6].

The cultural heritage is defined according to the legislation in force in Romania by Law no. $182 / 2000$ as consisting of all the goods that constitute a testimony and an expression of beliefs, knowledge, values and national traditions, regardless of their property regime. By the notion of cultural heritage means the existence of both a material and an intangible component, both being equally complex and varied. 
Heritage is a good that marks our existence, because it is everything that our ancestors considered to be so precious that they felt the need to leave it as a legacy and enjoy it. Heritage is an ideal resource for sustainable development - especially for local communities - provided we know how to value it. A recent ranking of the most visited cities in the world proves that the decisive element in choosing tourist destinations is the heritage that these cities have. An exceptional tourist network has developed around the natural and cultural assets and the areas where the intangible cultural heritage has been registered [8].

The tourism industry have always tried to promote the "local attractions", that would mean something for each specific place, that would individualise each touristic market. Therefore, the cultural heritage, being unique, in each of the cases, by its essence, comes as the first option for promoting a certain place. Museums have the advantage of being able to bring together, in only one building, and in a very attractive manner, all the knowledge about one region, one country, one culture [9].

Museums constitute an important resource for Cultural Tourism for several reasons: their status as cultural mediators and the diversity of their collections, their category (whether public or private and national, regional or local), and their conditions of multiplicity, uniqueness, freedom, flexibility and creative potentiality. Legislation for the promotion of a tourism which includes investments and interventions in areas of heritage value, should ensure that preservation of cultural and natural heritage shall take precedence over economic interests, where there is a risk of irreversible damage [9].

From an economic point of view, commercialisation of cultural tourism based on heritage resources should include profitability in its economic, social and environmental dimensions. Participation of museums in guided tours entails designing and complementing the cultural offering, in addition to being integral elements of the network of tourist attractions at each location. Museums can also be meeting points and points of departure for other itineraries and services, such as places of interest to tourists, restaurants, transportation, handicrafts, etc [9].

The natural resources of the Danube space create the adequate frame for practicing different forms of tourism, which could be efficiently diversified and developed. Calarasi County has an attractive tourist potential that allows the developing of different forms of tourism: cultural, religious, green tourism and agro tourism. A special attraction is represented by architectural, historical and cultural objectives [14].

One of the most important tourist attractions in Calarasi County is the Lower Danube Museum, a public cultural institution, of county and 
regional importance. The museum is occupied with collection, preservation, research, restoration, communication and exposure, for the purpose of knowledge, education and recreation, material and spiritual testimonies of the existence and evolution of human communities as well as of the environment.

The museum's building is an architectural monument of the late 19th century. The expositions show archaeological pieces (ceramics, antropomorphic and zoomorphic figures, winds, tools, fragments of neoeneolithic edifices from the Sultana - Malu Rosu archaeological site, Roman anthropomorphic plaster, Roman opal collection, enamelled ceramics and Byzantine adornments at the Pacuiul lui Soare), ancient and medieval numismatics, exhibits illustrating local history, ethnography collections and modern and contemporary Romanian art [1].

The Museum in Calarasi was founded in 1951 in a nationalized 6room building, located near the town hall, on St. Nicholas Street, behind the church of the same name. As a result of the rapid growth of heritage, it began to function in 1954, having an archaeological profile. By the Administrative-Territorial Organization Act of 1968, the Ialomita County with its residence in Slobozia was re-established. Between 1968 - 1981 the Museum of Calarasi was a department of history and archeology of the Ialomita County Museum. In 1981, the Archaeology Section was transformed into the Calarasi County Museum, so that in 1990 it can be assigned by the Commission of Museums and Collections to the Ministry of Culture the title of Museum of the Lower Danube [5].

In 2012, it opened to the Archeology Department of the Lower Danube Museum. The building has been designed and equipped with modern state-of-the-art equipment, which ensures security in accordance with the legislation in force. This fact made possible the premiere exhibition of some exceptional pieces that are part of the Museum's Treasury (coins, gold and silver ornaments, etc.), a heritage that illustrates the evolution of Danube communities from prehistory to the end of antiquity.

Among the pieces with treasure value exhibited in the Archeology section, there are also the clay feet that we will present below.

N. Harțuche and O. Bounegru, presenting the survey carried out in Medgidia, Constanța County between 1957-1958, refer to two "human feet" made of burnt clay, discovered in level III, attributed to Gumelniţa culture. The two objects were placed near the hearth of the house no. 3 and were made of a good quality paste, being covered with "a thin layer of mattelooking engobe". The pieces have the same dimensions (L-130 mm, H-75 
$\mathrm{mm}$ ), forming a pair, and do not present details, for this reason being put into the category of "boot last" stem [4].

As early as 1965, Ion Spiru mentioned the discovery in the area of Plosca commune, Teleorman county of a piece of clay, attributed to the Gumelnița culture, "representing the right paw of a human foot", which had a circular hole in the upper part, in the ankle area, which crosses the piece horizontally. From under the hole, on the inside, there is a curved line at approximately right angles that continues to the tip of the foot, parallel with the sole. On the outside, the line starts from the top and breaks towards the middle of the sole. It has a length of $117 \mathrm{~mm}$ and a height of $83 \mathrm{~mm}$. The fact that there are no anatomical elements, led the author to say that it is a possible representation of a form of footwear [10].

In 1979, Ion Spiru and Corneliu Beda presented another piece from the category of those that suggest the human foot, in this case, left foot, discovered in the tell from Plosca, in 1970. The paste the object is made from is well burned, and has a reddish colour, with small pebbles in its composition. On the surface, the piece is polished and varnished, and the sole is flat. It has a continuous incised line at the base of the sole, on either side of it, but without reaching the heel. From the top (where it is torn) two parallel incised lines descend towards the fingertips. It is $57 \mathrm{~mm}$ high and 97 $\mathrm{mm}$ long. About this artefact, the authors state that it does not represent the foot of an idol [11].

In 1987, Mihai Şimon and Done Şerbănescu referred to a "boot last" stem discovered in the Gumelnița tell of Şeinoiu, Călăraşi County, during the excavations from 1985. It came from a house and it has a good quality paste, black with "smoky spots", it has marked fingers (two are broken) and has a horizontal perforation at the top. It has $68 \mathrm{~mm}$ in the length of a height of $43 \mathrm{~mm}$. The authors state that it is a representation of a naked foot, given the fact that the piece has marked toes [12].

Along with this one 7 more pieces were presented, 6 of them discovered in the eponym site Gumelniţa and one from Căscioarele, Călăraşi county.

A representation of a human foot, discovered at Gumelnița in 1963, which depicts the left limb, modelled in "brown with reddish spots", mechanically polished on the outside, with a decoration that suggests the details of "a sandal or a shoe". It is $151 \mathrm{~mm}$ long and $90 \mathrm{~mm}$ high [12].

Another piece, discovered at Gumelnița in 1961, shows the right foot, has poor quality paste, is decorated with fine incisions and has a hole at the top that crosses the piece obliquely. It is $100 \mathrm{~mm}$ long and $74 \mathrm{~mm}$ long [12]. 
The third object from Gumelniţa, which shows the right foot, was discovered in 1971. It is modelled from common brownish paste keeping traces of white paste from place to place. It has an oblique hole at the top, like the piece presented above. It is $78 \mathrm{~mm}$ long and $75 \mathrm{~mm}$ high [12].

The next piece, also discovered at Gumelniţa, is fragmentary. It is modelled from a good quality paste, with a "smoky black" colour and has two small horizontal lines at the top, which could suggest the shoes. It has a horizontal hole at the top. It is $92 \mathrm{~mm}$ long and $57 \mathrm{~mm}$ high [12].

The fifth artefact, also discovered in Gumelniţa in 1959, shows the right leg and is modelled from a common-use paste, brown-reddish. It has a wide, vertical hole at the top, the authors believing that this type of object could be used as "wicks or rushlight, probably in some cult practices". It is $118 \mathrm{~mm}$ long and $90 \mathrm{~mm}$ high [12].

The next finding discovered in Gumelnița in 1968, in a house, shows the right foot and it is modelled from an inferior quality paste. It has figurate fingers at the bottom, but also at the top, through deep incisions. It has a horizontal hole at the top. It is $87 \mathrm{~mm}$ long and $30 \mathrm{~mm}$ high [12].

The last item, discovered in 1925 at Căscioarele, represents the right foot, it is modelled in a black paste, has an oblique hole at the top and has incised lines, which could suggest footwear. It is $100 \mathrm{~mm}$ long and $57 \mathrm{~mm}$ high [12].

In 2010, A. Frânculeasa and O. Negrea presented the results of a survey conducted in 2009, on the site Seciu. Along with the ceramic material, stone tools, flint, horn and bone, also clay plastic inventory was presented. Thus, is mentioned an anthropomorphic foot of the "boot last" type, with a length of $108 \mathrm{~mm}$ and a height of $97 \mathrm{~mm}$ and ankle represented, lacking other details; it has no hole [3].

In 2010, C. E. Ştefan presented a foot made of clay, the left foot, discovered at Căscioarele "Ostrovel" in 1967 with a length of $123 \mathrm{~mm}$ and a height of $90 \mathrm{~mm}$. It has no modelled fingers [13].

Another such discovery from Căscioarele "Ostrovel", represents the right leg, with a length of $90 \mathrm{~mm}$ and a height of $75 \mathrm{~mm}$, it has an oblique perforation at the top, on the left. It has lines that might suggest the shoe but no modelled fingers either [13].

Also from the Căscioarele "Ostrovel", there is a fragmentary left leg, with a length of $58 \mathrm{~mm}$ and a height of $62 \mathrm{~mm}$. It has lines that might suggest the shoe but again it has no modelled fingers [13].

The last artefact of this kind presented is discovered in Cuneşti "Măgura Cuneştilor". It is a right foot and it has a horizontal perforation at the top. We do not have shaped toes is this case neither [13]. 


\section{Research Questions/Aims of the research}

Although the number of "boot last" stems discovered in the area of Gumelniţa culture on the Romanian territory is small, M. Simon and Done Şerbănescu tried to classify them, from a typological point of view. They presented two main variants, namely: the rendered foot worn (without anatomical marks) and the barefoot (with anatomical marks). The two variants were divided into sub-variant. Thus, the first main category was divided into three subcategories, the classification was made according to the presence or absence of anatomical marks, as follows: parts without details, with details, and with a wide hole at the top. Regarding the second main variant, we find two sub-variant, established according to the anthropomorphic details, namely: with the upper part terminated by a truncated cone-shaped tip and with the upper part provided with a wide hole [12].

Previously, A. Niţu proposed four variants of classification of these artefacts: barefoot or shod solid foot, solid foot representing the shod foot or suggesting the shoe, barefoot, representing the shoe, serving as vessel support and vessel-shaped foot representing the shoe [7].

\section{Research Methods}

As a working methodology, for a clearer analysis, we considered the more or less known discovery context, the technical data, and last but not least the technological considerations, without overlooking possible interpretations of these objects.

The objects we refer to came from accidental discoveries, following agricultural works, only one, the one from Sultana - Malu Roşu, being discovered near the tell.

The fact that we do not have an appropriate archaeological context for their discovery, does not allow us an exact chronological classification, but based from the morphological features and by identifying analogies, we will attribute these artefacts to B phase of Gumelniţa Culture.

We present in the following lines a catalogue of these artefacts:

1. "Boot last" stem - Gumelnița culture, 5th - 4th century BC. It renders the shape of the left foot; grey paste; good conservation state; the upper part restored, $105 \mathrm{~mm}$ long, $50 \mathrm{~mm}$ wide and $84 \mathrm{~mm}$ high. It was discovered after some agricultural works; inv. no.: 9148; classification order: 2099/06.03.2008 - class: Treasure [Pl.2,fig.1].

2. "Boot last" stem - Gumelnița culture, 5th - 4th century BC. It renders the shape of the right foot; low-quality grey paste; good conservation state; the upper part rounded, $88 \mathrm{~mm}$ long, $43 \mathrm{~mm}$ wide and 60 
$\mathrm{mm}$ high. It was discovered after some agricultural works; inv. no.: 9138; classification order: 2099/06.03.2008 - class: Treasure [Pl.2,fig.2].

3. "Boot late" stem - Gumelnița culture, 5th - 4th century BC. It renders the shape of the left foot; low quality gray paste; good conservation state; the upper part restored, $153 \mathrm{~mm}$ long, $68 \mathrm{~mm}$ wide and $106 \mathrm{~mm}$ high. It was discovered after some agricultural works; inv. no.: 9216 [Pl.2,fig.3].

4. "Boot last" stem - Gumelniţa culture, $5^{\text {th }}-4^{\text {th }}$ century BC. It renders the shape of the right foot; low-quality grey paste; good conservation state although it has a crack on the upper part that crosses the artefact horizontally; $153 \mathrm{~mm}$ long, $68 \mathrm{~mm}$ wide and $106 \mathrm{~mm}$ high. It was discovered after some agricultural works; there is the possibility that it is the pair of the artefact presented above; inv. no.: 9217 [Pl.2,fig.4].

5. "Boot late" stem - Gumelnița culture, $5^{\text {th }}-4^{\text {th }}$ century BC. It renders the shape of the left foot; low-quality brownish paste; whole original artefact in a good conservation state; $43 \mathrm{~mm}$ long, $20 \mathrm{~mm}$ wide and $30 \mathrm{~mm}$ high. It was randomly discovered on "Măgura Cuneşti" after some agricultural works; inv. no.: 9220; classification order: 2099/06.03.2008 class: Treasure [Pl.2,fig.5].

6. "Boot late" stem - Gumelnița culture, $5^{\text {th }}-4^{\text {th }}$ century BC. It renders the shape of the right foot; low quality green greyish paste; good conservation state but fragmentary, the upper part is missing; $43 \mathrm{~mm}$ long, $26 \mathrm{~mm}$ wide and $18 \mathrm{~mm}$ high. It was randomly discovered close by SultanaMalu Roşu 's tell; inv. no.: 36951 [Pl.2,fig.6].

The first four pieces presented by us above were previously analyzed by Vasile Culică in an article from 1973, which presented the context of their discovery [2].

\section{Conclusions}

Although we do not have a large and unitary batch of pieces from a typological point of view, some clarifications are necessary.

The context in which the "cobblestone" legs from the general archaeology collection of the Lower Danube Museum were discovered is clear for the first four pieces, but it is not relevant from an archaeological and scientific point of view.

In terms of size, the pieces presented have lengths between $43 \mathrm{~mm}$ (Sultana piece) and $153 \mathrm{~mm}$, and heights from $18 \mathrm{~mm}$ to $106 \mathrm{~mm}$.

If we discuss the paste from which the six pieces presented by us are modelled, it can be seen that they all have a poor quality paste, five of them having a grey colour and a brick one. 
Regarding the type of representation, none of the pieces we have addressed here show any anatomical signs (toes, ankle or sole) or lines that could suggest a shod foot.

Even if we didn't have only whole pieces at our disposal, we could still point out that out of the six analyzed by us, only one has a horizontal hole at the top.

Regarding the possible interpretations of these pieces, A. Niţu is the one who presents for the first time the meanings of the representation of the human foot in the Carpatho-Danubian space from the Neo-Eneolithic period. He finds two types of meanings for this type of play: the representation of divinity according to the pars pro toto principle and the use of "clay feet" during ex-voto healing, rituals of thanksgiving dedicated to divinity [7].

M. Şimon and D. Şerbănescu stated that the representations of the human foot from the area of the Gumelnița culture are related to the symbols of purity, power and the presence of the divinity. Their presence in homes, as well as their perforation (which allowed them to be suspended in various places), could suggest a deity whose role was to protect the house [12].

Without bringing many novelty elements from a technological and typological point of view, the publication of this type of artefacts aims to complete the repertoire of discoveries with unique pieces that find analogies in the cultural environment of Gumelnița.

\section{Acknowledgement}

This work is supported by project POCU 125040, entitled "Development of the tertiary university education to support the economic growth PROGRESSIO", co-financed by the European Social Fund under the Human Capital Operational Program 2014-2020.

\section{References}

[1] Institutul Național al Patrimoniului. Muzee şi Colecţii din România [Internet]. Institutul Naţional al Patrimoniului. [cited 2020 Sep 14]. Available from: http://ghidulmuzeelor.cimec.ro/id.asp?k=203

[2] Culică V. Obiecte ceramice cu aspect de calapod din aşezarea neolitică de la Cuneşti. SCIV. 1973;24(1):103-108.

[3] Frînculeasa A, Negrea O. Un sit din epoca neo-eneolitică în zona colinară a Munteniei - Seciu, jud. Prahova. BMJT. 2010;2:45-68. 
[4] Harțuche N, Bounegru O. Săpăturile arheologice de salvare de la Medgidia, jud. Constanța (1957-1958). Pontica. 1997;30:17-104.

[5] Muzeul Dunării de Jos. Arheologie - Istorie [Internet]. Călăraşi: Muzeul Dunării de Jos; [cited 2020 Sep 14]. Available from: http://mdj-calarasi.ro/

[6] Niculescu G. Turismul şi renaşterea culturală. Analele Universității “Constantin Brâncuşi” din Târgu Jiu. Seria Economie. 2009;3:369-376.

[7] Nițu A. Despre reprezentarea piciorului divin în plastica neo-eneolitică carpatodunăreană. Apulum. 1947-1949;3:107-135.

[8] Nițulescu V. Patrimoniu, dezvoltare locală şi turism [Internet]. ABC-ul Patrimoniului; [cited 2020 Sep 11]. Available from: https://patrimoniu100.ro/abc-ul-patrimoniului/patrimoniu-dezvoltare-localasi-turism/

[9] Nitulescu VŞ. Museums of today: A role to play in the tourism industry. CCDJ. 2009;27:7-14.

[10] Spiru I. Câteva descoperiri paleolitice şi neolitice în raionul Alexandria. SCIV. 1965;16(2):307-310.

[11] Spiru I, Beda C. Tell-ul Gumelnițean de la Plosca, jud. Teleorman. Cercetări Arheologice. 1979;3:401-404.

[12] Şimon M, Şerbănescu D. Considerații privind reprezentarea simbolică a piciorului uman din aria culturii Gumelnița. CCDJ. 1987;3-4:29-34.

[13] S.tefan CE. New data concerning the representation of human foot in the Gumelnița culture. Studii de Preistorie. 2010;7:125-136.

[14] Ştefan D. Cross border tourism at Lower Danube - Brief presentation. CCDJ. 2009;27:15-20. 


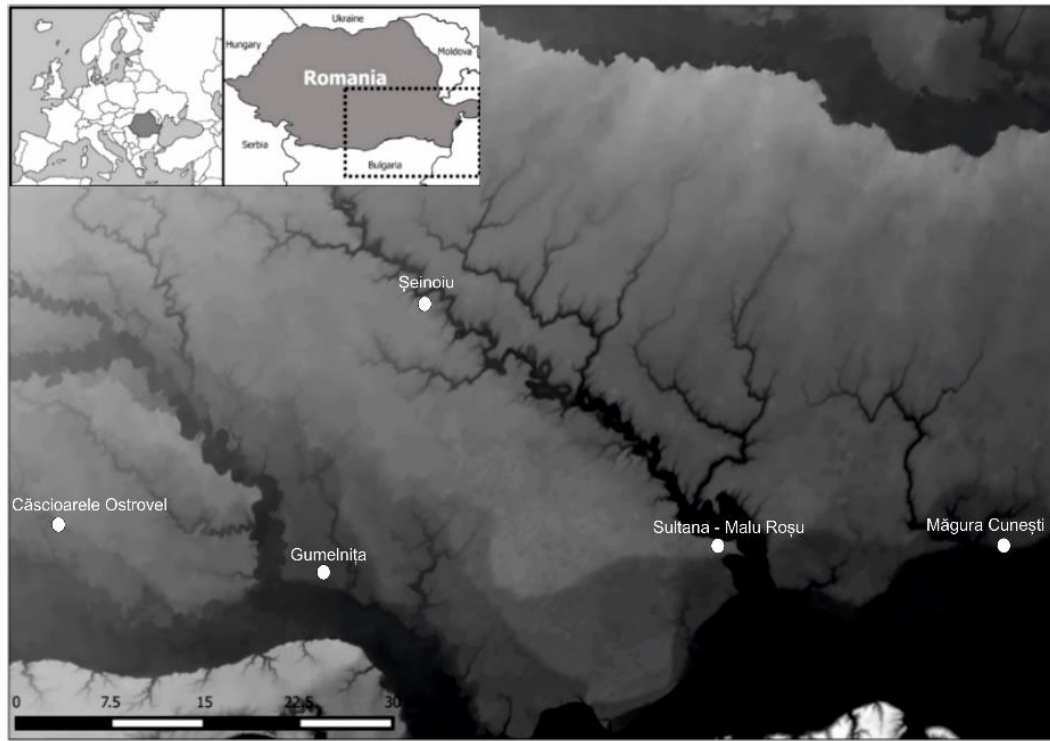

PI. 1. Map with foot shoe discoveries from Muntenia (apud Google Earth)

Source: Authors creation/capture using Google Earth

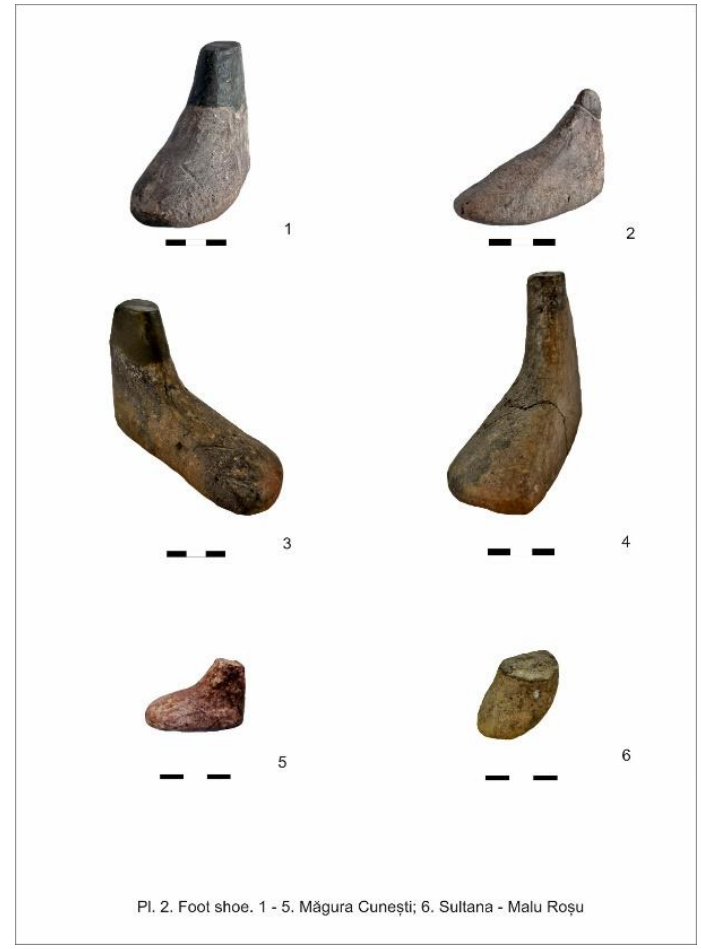

Source: Authors creation 